\title{
Correlation Matrix on Bottle Gourd for Yield and its Attributing Traits
}

\author{
Pankaj Kumar Ray ${ }^{*}$, Anupam Adarsh', Sriom² and Rajat Kumar Singh ${ }^{2}$ \\ ${ }^{1}$ Department of Horticulture (Vegetables and Floriculture), Bihar Agriculture University, \\ Bhagalpur, Bihar, India \\ ${ }^{2}$ Department of Vegetable Science, N.D.U.A.\&T., Kumarganj, Faizabad, India \\ *Corresponding author
}

\section{A B S T R A C T}

\section{Keywords \\ Correlation, Experiment, Yield-contributing, Attributes. \\ Article Info \\ Accepted: \\ 19 May 2017 \\ Available Online: \\ 10 June 2017}

An experiment was conducted for 12 different traits in bottle gourd (Lagenaria siceraria (Molina) standl) comprising 45 hybrids obtained by crossing 10 parental lines in diallel mating design to study the correlation and direct and indirect effects of different characters on fruit yield. The experiment was conducted in a randomized block design. The overall analysis reveals that fruit yield was positively and significant correlated with fruit/plants. The path analysis indicated that number of fruits per plant, fruit weight, fruit length, primary branches/plant had positive direct effect on fruit yield while rest of the traits has indirect effect on fruit yield/plant. Association of this yield-contributing character with yield and among its components is important for making selection in the breeding program and facilitates the partitioning of correlation coefficients on the direct and indirect effects of component characters on yield and any other attributes.

\section{Introduction}

Bottle gourd (Lagenaria siceraria (Molina) Standl) is an important crop of Cucurbitaceae family having chromosome number $2 n=22$. It is native of tropics and grown in tropical and sub-tropical areas. It is known by various names like white flowered gourd, trumpet gourd, calabash gourd (Adarsh et al., 2015). This vegetable is known for its nutraceuticals and pharmaceuticals value. Its tender fruits are used as vegetable and for making sweets in Africa and Asia (Janaranjani and Kanthaswamy, 2015). It is herbaceous vine bearing crop grow upto $5 \mathrm{~m}$ and simple, alternate leaves with separated lobes and velvety texture having white staminate and pistillate flower (Rashid, 2004). The dried fruits can be used as containers, utensils and some musical instruments. It contains water (96.1g), protein $(0.2)$, minerals $(0.5)$, fat $(2.5)$, fiber (0.6) and energy (12kcal) per $100 \mathrm{gm}$ of edible fruit (Husna et al., 2011). Bottle gourd is an herbaceous, annual climbing plant with long, strong tendrils and simple leaves. Fruits are globular, club shaped with hard and tough rind. It is cultivated throughout the country during summer and rainy season. Bottle gourd is widely cultivated during spring-summer season (Seshadri and Parthasarathy, 2002). But the average yield is very low compared to other bottle gourd variety due to lack of well 
acceptable variety with high yield potential and better quality (Ara et al., 2014).

The yield potential and development of high yielding variety of this crop needs systematic breeding approach. For this genetic improvement of crop can be done to estimate correlation matrix between yield and its contributing traits. An understanding of nature and magnitude of the variability among the genetic stocks of bottle gourd is importance for the breeders. Being monoecious and cross pollinated nature of crop good knowledge of genetic wealth helps in identifying desirable cultivars for commercial cultivation because identification of genetically pure strain is important for planning breeding programme (Ara et al., 2014). The strength and direction of correlation depend on the nature of experimental maturity and growing conditions (Ara et al., 2014). The knowledge of nature and magnitude of the variability among the genetic stocks/germplasm of bottle gourd is importance for the breeders, a good knowledge of genetic stocks/wealth help in identifying desirable genotype for commercial cultivation.

The careful assessment of variation and their association to gain complexity of mechanism provides information about genotypic association between the characters and that might be useful as an index of selection. It helps to decide the dependability of the characters that have little or no character could be hurtful for proper choice of parents for hybridization. Though, the present experiment was conducted to determine the effect of genotypical and phenotypical correlation matrix on yield and its attributing traits.

\section{Materials and Methods}

The present investigation was carried out at the Department of Horticulture, Narendra Dev
University of Agriculture and Technology, Faizabad. Ten parents of bottle gourd namely Pusa Naveen(P1), NDBG-202-LF(P2), NDBG-70-2(P3), NDBG-517(P4), NDBG601(P5), NDBG-603(P6), NDBG-624(P7), NDBG-625(P8), NDBG-749-2(P9), NDBG651(P10) were selected for the experiment. These lines were crossed in half diallel mating design.

The 10 parents and $45 \mathrm{~F} 1$ were raised in Randomized Block Design (RBD) with three replications. An inter-row spacing of $2.0 \mathrm{~m}$ and intra row spacing of $1.5 \mathrm{~m}$ was adopted. The observation were recorded were days to $1^{\text {st }}$ staminate, Pistillate flower anthesis, node no. to 1st staminate, Pistillate flower anthesis, vine length, number of primary branches, sex ratio, days to first fruit harvest, fruit length, fruit circumference, average fruit weight, fruit $(\mathrm{kg})$, fruit/plant.

The correlations were worked out and Path coefficient analysis was carried out by the method suggested partitioning the genotypic correlation coefficient into measures of direct and indirect effects.

\section{Results and Discussion}

The genotypes and phenotypic correlation matrix between yield and its components traits were estimated and presented in table 1.

Correlation matrix confers significant variation among the genotypes for most of the traits under study. Correlation matrix were highest for days to anthesis of $1^{\text {st }}$ pistillate flower anthesis followed by days to first fruit harvest, average fruit weight and fruit yield/plant among the genotypes at both genotypic and phenotypic level whereas Ara et al., (2014) reported that correlation coefficient of 55 genotypes for 12 traits was recorded highest for nodal position of first female flower opening followed by yield/plant, sex ratio among the genotypes. 
The experiment shows that genotypic correlation matrix for fruit yield/plant appeared to be higher than phenotypical matrix. It indicated that fruit yield had inherent association among various characters. Correlation studies provide information regarding selection for one character will result in progress for all correlated characters.

The fruit length and fruits/plant has positive correlation with fruit yield/plant at both genotypic and phenotypic level whereas all other traits are inter-correlation with fruit yield/plant. Though, the selection will be based on fruit length and fruits/plant.

Days to $1^{\text {st }}$ pistillate flower anthesis has negative correlation with days to $1^{\text {st }}$ fruit harvest, vine length, fruit length, fruit circumference, average fruit weight, while node number to $1^{\text {st }}$ pistillate flower anthesis has negative correlation with fruit yield/plant. Fruit length is highly significant and positively corelations with fruit yield/plant both at genotypic and phenotypic level.

Total yield (TY) was positively correlated with fruit circumference, average fruit weight and number of fruits/plant while it was negative correlation with all other traits and this line in finding of Janaranjani et al., 2015. On the contrary, Total yield was highly negatively correlated with staminate or pistillate flower anthesis, days to $1^{\text {st }}$ fruit harvest, vine length, primary branches and fruit length which indicate early maturity small size of fruits.

Path matrix analysis was carried out to find out direct and indirect effects of twelve characters of present study on fruit yield per plant and the results are presented in table 2 . Path analysis shows that no. of fruits/plant was positively correlated with fruit yield/plant whereas other trait has only negligible direct and indirect effects on fruit yield/plant. Though, all the traits are reliable for fruit yield/plants except primary branches and average fruit weight. The residual effect is high at phenotypic level as compared to genotypic level.

The results of the path analysis shows maximum direct positive effect had observed on no. of fruits/plant had the [Phenotypic (1.491), Genotypic (1.518)] followed by average fruit weight [Phenotypic (1.105), Genotypic (1.144)], primary branches/plant [Phenotypic (0.091), Genotypic (0.131)] and fruit length [Phenotypic (0.052), Genotypic (0.049)] (Table 2) whereas days to 1st staminate flower anthesis [Phenotypic (0.027), Genotypic (-1.132)], days to 1 st pistillate flower anthesis [Phenotypic (0.017), Genotypic (-0.119)], node no. to 1st staminate flower anthesis [Phenotypic ($0.025)$, Genotypic (-0.049)], node no. to 1 st pistillate flower anthesis [Phenotypic (0.038), Genotypic (-0.021)], days to 1st fruit harvest [Phenotypic (-0.041), Genotypic (0.092)] and vine length [Phenotypic (-0.013), Genotypic (-0.065)] has direct negative effect on fruit yield/plant. The contributions of yield components like no. of fruit per plant were highest for present study.

It helps in building up correlation with yield. The contributions of negative and positive direct or indirect effects via different parameters were responsible for exhibiting the positive total genotypic correlation with yield.

The estimated residual effect was 0.2327 (Phenotypical) $0.2494 \quad$ (Genotypical) indicating that the variability in Bottle gourd yield was mostly contributed by these traits. These findings are in conformation with the work of Husna et al., 2011; Parvathi et al., 2006. 


\begin{tabular}{|c|c|c|c|c|c|c|c|c|c|c|c|c|c|}
\hline \multicolumn{14}{|c|}{ Table.1 Genotypical and phenotypical correlation matrix } \\
\hline \multicolumn{2}{|l|}{ 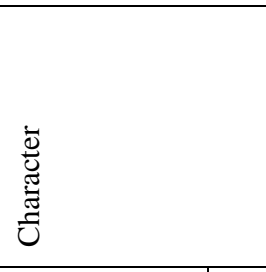 } & 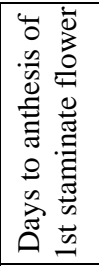 & 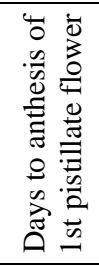 & 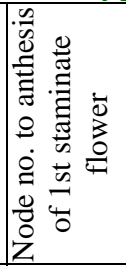 & 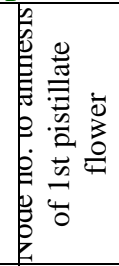 & 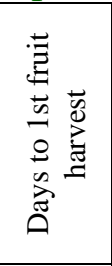 & 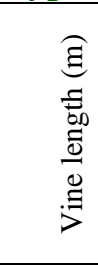 & 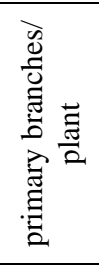 & 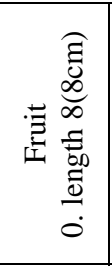 & 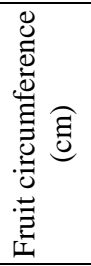 & 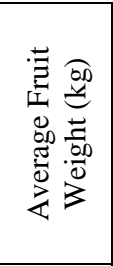 & 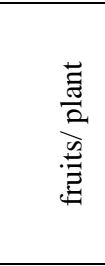 & 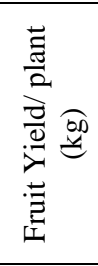 \\
\hline $\begin{array}{l}\text { Days to } \\
\text { anthesis of 1st } \\
\text { staminate } \\
\text { flower }\end{array}$ & G & 1.00 & $0.98^{*}$ & $0.35^{*}$ & 0.05 & $0.91^{*}$ & -0.44 & $0.27^{\star \star}$ & $-0.33^{*}$ & -0.19 & -0.50 & $0.25^{\star *}$ & -0.25 \\
\hline & $\mathrm{P}$ & 1.00 & $0.96^{*}$ & $0.30^{*}$ & 0.05 & $0.89^{*}$ & -0.38 & $0.27^{* *}$ & $-0.32^{*}$ & -0.18 & -0.47 & $0.24^{* *}$ & -0.23 \\
\hline $\begin{array}{l}\text { Days to } \\
\text { anthesis of 1st } \\
\text { pistillate } \\
\text { flower }\end{array}$ & G & & 1.00 & $0.34^{*}$ & 0.11 & $0.92^{*}$ & -0.40 & $0.28^{* *}$ & $0.29^{* *}$ & -0.21 & -0.45 & $0.20^{* *}$ & $0.28^{* *}$ \\
\hline & $\mathrm{P}$ & & 1.00 & $0.28^{* *}$ & 0.11 & $0.90^{*}$ & -0.35 & $0.27^{* *}$ & $0.29^{* *}$ & -0.19 & -0.42 & 0.19 & $0.26^{\star *}$ \\
\hline $\begin{array}{l}\text { Node no. to } \\
\text { anthesis of } 1 \mathrm{st} \\
\text { staminate } \\
\text { flower }\end{array}$ & G & & & 1.00 & $0.67^{*}$ & $0.32^{*}$ & 0.14 & $0.37^{*}$ & -0.10 & 0.09 & 0.15 & $0.28^{* *}$ & $-0.31^{*}$ \\
\hline & $\mathrm{P}$ & & & 1.00 & $0.56^{*}$ & $0.29^{* *}$ & 0.15 & $0.29^{* *}$ & -0.10 & 0.07 & 0.08 & -0.17 & $0.22^{* *}$ \\
\hline $\begin{array}{l}\text { Node no. to } \\
\text { anthesis of } 1 \text { st } \\
\text { pistillate } \\
\text { flower }\end{array}$ & G & & & & 1.00 & 0.17 & $0.35^{*}$ & 0.19 & 0.19 & 0.01 & $0.44^{*}$ & $-0.43^{*}$ & -0.20 \\
\hline & $\mathrm{P}$ & & & & 1.00 & 0.17 & $0.29^{* \star}$ & 0.17 & 0.15 & -0.01 & $0.36^{*}$ & $-0.36^{*}$ & -0.17 \\
\hline $\begin{array}{l}\text { Days to } 1 \mathrm{st} \\
\text { fruit harvest }\end{array}$ & $\mathrm{G}$ & & & & & 1.00 & -0.38 & $0.27^{* *}$ & -0.28 & -0.27 & $-0.42^{*}$ & 0.18 & $0.27^{* *}$ \\
\hline & $\mathrm{P}$ & & & & & 1.00 & -0.33 & $0.25^{\star *}$ & -0.28 & -0.26 & $-0.39^{*}$ & 0.17 & $0.25^{* *}$ \\
\hline $\begin{array}{l}\text { Vine length } \\
\text { (m) }\end{array}$ & $\mathrm{G}$ & & & & & & 1.00 & $0.44^{*}$ & $0.43^{*}$ & 0.23 & $0.58^{*}$ & -0.54 & -0.12 \\
\hline & $\mathrm{P}$ & & & & & & 1.00 & $0.41^{*}$ & $0.38^{*}$ & 0.20 & $0.48^{*}$ & -0.45 & -0.09 \\
\hline $\begin{array}{l}\text { primary } \\
\text { branches/ } \\
\text { plant }\end{array}$ & G & & & & & & & 1.00 & -0.05 & -0.07 & -0.05 & -0.03 & -0.05 \\
\hline & $\mathrm{P}$ & & & & & & & 1.00 & -0.04 & -0.05 & -0.05 & -0.03 & -0.04 \\
\hline $\begin{array}{l}\text { Fruit length } \\
\text { (cm) }\end{array}$ & $\mathrm{G}$ & & & & & & & & 1.00 & -0.02 & $0.57^{\star}$ & -0.43 & 0.04 \\
\hline & $\mathrm{P}$ & & & & & & & & 1.00 & 0.00 & $0.55^{\star}$ & -0.42 & 0.04 \\
\hline $\begin{array}{l}\text { Fruit } \\
\text { circumference } \\
(\mathrm{cm})\end{array}$ & G & & & & & & & & & 1.00 & $0.44^{*}$ & -0.43 & -0.19 \\
\hline & $\mathrm{P}$ & & & & & & & & & 1.00 & $0.42^{*}$ & -0.41 & -0.17 \\
\hline $\begin{array}{l}\text { Average Fruit } \\
\text { Weight }(\mathrm{kg})\end{array}$ & $\mathrm{G}$ & & & & & & & & & & 1.00 & -0.79 & -0.06 \\
\hline & $\mathrm{P}$ & & & & & & & & & & 1.00 & -0.78 & -0.03 \\
\hline $\begin{array}{l}\begin{array}{l}\text { Fruits } \\
\text { /plant }\end{array} \\
\end{array}$ & $\mathrm{G}$ & & & & & & & & & & & 1.00 & 0.63 \\
\hline & $\mathrm{P}$ & & & & & & & & & & & 1.00 & 0.62 \\
\hline
\end{tabular}




\begin{tabular}{|c|c|c|c|c|c|c|c|c|c|c|c|c|c|c|}
\hline \multicolumn{15}{|c|}{ Table.2 Path matrix of fruit yield/plant } \\
\hline 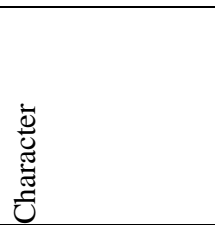 & & 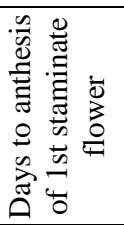 & 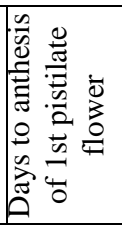 & 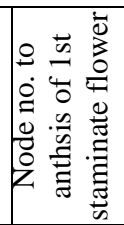 & 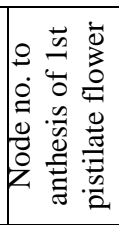 & 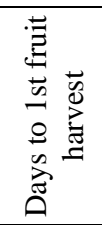 & 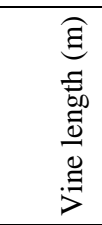 & 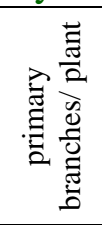 & 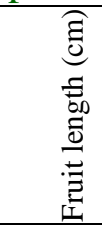 & 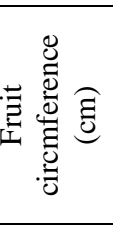 & 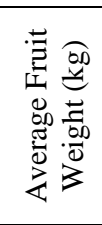 & $\frac{\vec{\Xi}}{\stackrel{\Xi}{2}}$ & 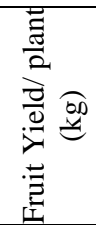 & 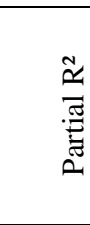 \\
\hline $\begin{array}{l}\text { Days to } \\
\text { anthesis of 1st } \\
\text { staminate } \\
\text { flower }\end{array}$ & $\mathrm{P}$ & -0.027 & -0.026 & -0.008 & -0.001 & -0.024 & 0.010 & -0.007 & 0.009 & 0.005 & 0.013 & -0.007 & -0.233 & 0.006 \\
\hline & $\mathrm{G}$ & -0.132 & -0.129 & -0.047 & -0.007 & -0.120 & 0.058 & -0.036 & 0.043 & 0.025 & 0.065 & -0.033 & -0.245 & 0.032 \\
\hline $\begin{array}{l}\text { Days to } \\
\text { anthesis of } 1 \mathrm{st} \\
\text { pistillate flower }\end{array}$ & $\mathrm{P}$ & -0.017 & -0.017 & -0.005 & -0.002 & -0.016 & 0.006 & -0.005 & 0.005 & 0.003 & 0.007 & -0.003 & -0.262 & 0.005 \\
\hline & $\mathrm{G}$ & 0.117 & -0.119 & 0.040 & 0.013 & 0.110 & -0.047 & 0.033 & -0.035 & -0.024 & -0.054 & 0.024 & -0.276 & -0.033 \\
\hline $\begin{array}{l}\text { Node no. to } \\
\text { anthesis of } 1 \text { st } \\
\text { staminate } \\
\text { flower }\end{array}$ & $\mathrm{P}$ & -0.007 & -0.007 & -0.025 & -0.014 & -0.007 & -0.004 & -0.007 & 0.002 & -0.002 & -0.002 & 0.004 & -0.225 & 0.006 \\
\hline & $\mathrm{G}$ & -0.017 & -0.016 & -0.049 & -0.032 & -0.015 & -0.007 & -0.018 & 0.005 & -0.005 & -0.007 & 0.013 & -0.312 & 0.015 \\
\hline $\begin{array}{l}\text { Node no. to } \\
\text { anthesis of } 1 \mathrm{st} \\
\text { pistillate flower }\end{array}$ & $\mathrm{P}$ & -0.002 & -0.004 & -0.021 & -0.038 & -0.006 & -0.011 & -0.007 & -0.006 & 0.000 & -0.014 & 0.014 & -0.173 & 0.007 \\
\hline & $\mathrm{G}$ & -0.001 & -0.002 & -0.014 & -0.021 & -0.004 & -0.007 & -0.004 & -0.004 & 0.000 & -0.009 & 0.009 & -0.204 & 0.004 \\
\hline $\begin{array}{l}\text { Days to } 1 \mathrm{st} \\
\text { fruit harvest }\end{array}$ & $\mathrm{P}$ & -0.036 & -0.037 & -0.012 & -0.007 & -0.041 & 0.014 & -0.010 & 0.012 & 0.011 & 0.016 & -0.007 & -0.253 & 0.010 \\
\hline & $\mathrm{G}$ & -0.083 & -0.084 & -0.029 & -0.016 & -0.092 & 0.035 & -0.025 & 0.026 & 0.025 & 0.038 & -0.016 & -0.266 & 0.024 \\
\hline $\begin{array}{l}\text { Vine length } \\
(\mathrm{m})\end{array}$ & $\mathrm{P}$ & 0.005 & 0.005 & -0.002 & -0.004 & 0.004 & -0.013 & -0.005 & -0.005 & -0.003 & -0.006 & 0.006 & -0.091 & 0.001 \\
\hline & $\mathrm{G}$ & 0.029 & 0.026 & -0.009 & -0.023 & 0.025 & -0.065 & -0.029 & -0.028 & -0.015 & -0.038 & 0.035 & -0.119 & 0.008 \\
\hline $\begin{array}{l}\text { primary } \\
\text { branches/ plant }\end{array}$ & $\mathrm{P}$ & 0.024 & 0.024 & 0.026 & 0.015 & 0.023 & 0.037 & 0.091 & -0.004 & -0.005 & -0.004 & -0.002 & -0.044 & -0.004 \\
\hline & $\mathrm{G}$ & 0.036 & 0.037 & 0.049 & 0.025 & 0.036 & 0.058 & 0.132 & -0.006 & -0.009 & -0.006 & -0.004 & -0.048 & -0.006 \\
\hline $\begin{array}{l}\text { Fruit length } \\
\text { (cm) }\end{array}$ & $\mathrm{P}$ & -0.017 & -0.015 & -0.005 & 0.008 & -0.015 & 0.020 & -0.002 & 0.052 & 0.000 & 0.029 & -0.022 & 0.045 & 0.002 \\
\hline & $\mathrm{G}$ & -0.016 & -0.014 & -0.005 & 0.009 & -0.014 & 0.021 & -0.002 & 0.049 & -0.001 & 0.028 & -0.021 & 0.045 & 0.002 \\
\hline $\begin{array}{l}\text { Fruit } \\
\text { circmference } \\
(\mathrm{cm})\end{array}$ & $\mathrm{P}$ & 0.005 & 0.005 & -0.002 & 0.000 & 0.007 & -0.006 & 0.001 & 0.000 & $-\mathbf{0 . 0 2 7}$ & -0.011 & 0.011 & -0.173 & 0.005 \\
\hline & $\mathrm{G}$ & 0.006 & 0.007 & -0.003 & 0.000 & 0.009 & -0.008 & 0.002 & 0.001 & -0.035 & -0.015 & 0.015 & -0.190 & 0.007 \\
\hline $\begin{array}{l}\text { Average Fruit } \\
\text { Weight (kg) }\end{array}$ & $\mathrm{P}$ & -0.523 & -0.468 & 0.088 & 0.401 & -0.435 & 0.531 & -0.053 & 0.608 & 0.462 & 1.105 & -0.860 & -0.029 & -0.031 \\
\hline & $\mathrm{G}$ & -0.568 & -0.520 & 0.173 & 0.499 & -0.475 & 0.659 & -0.052 & 0.654 & 0.500 & 1.144 & -0.907 & -0.057 & -0.065 \\
\hline $\begin{array}{l}\text { No. of Fruits } \\
\text { /plant }\end{array}$ & $\mathrm{P}$ & 0.362 & 0.278 & -0.260 & -0.531 & 0.257 & -0.675 & -0.039 & -0.628 & -0.618 & -1.160 & 1.491 & 0.625 & 0.932 \\
\hline & $\mathrm{G}$ & 0.385 & 0.302 & -0.418 & -0.650 & 0.273 & -0.815 & -0.049 & -0.659 & -0.651 & -1.203 & 1.518 & 0.631 & 0.957 \\
\hline
\end{tabular}

R SQUARE $=0.938$ (Phenotypical) 0.946 (Genotypical)

RESIDUAL EFFECT $=0.2327$ (Phenotypical) 0.2494 (Genotypical) 


\section{Genotypical Correlations}

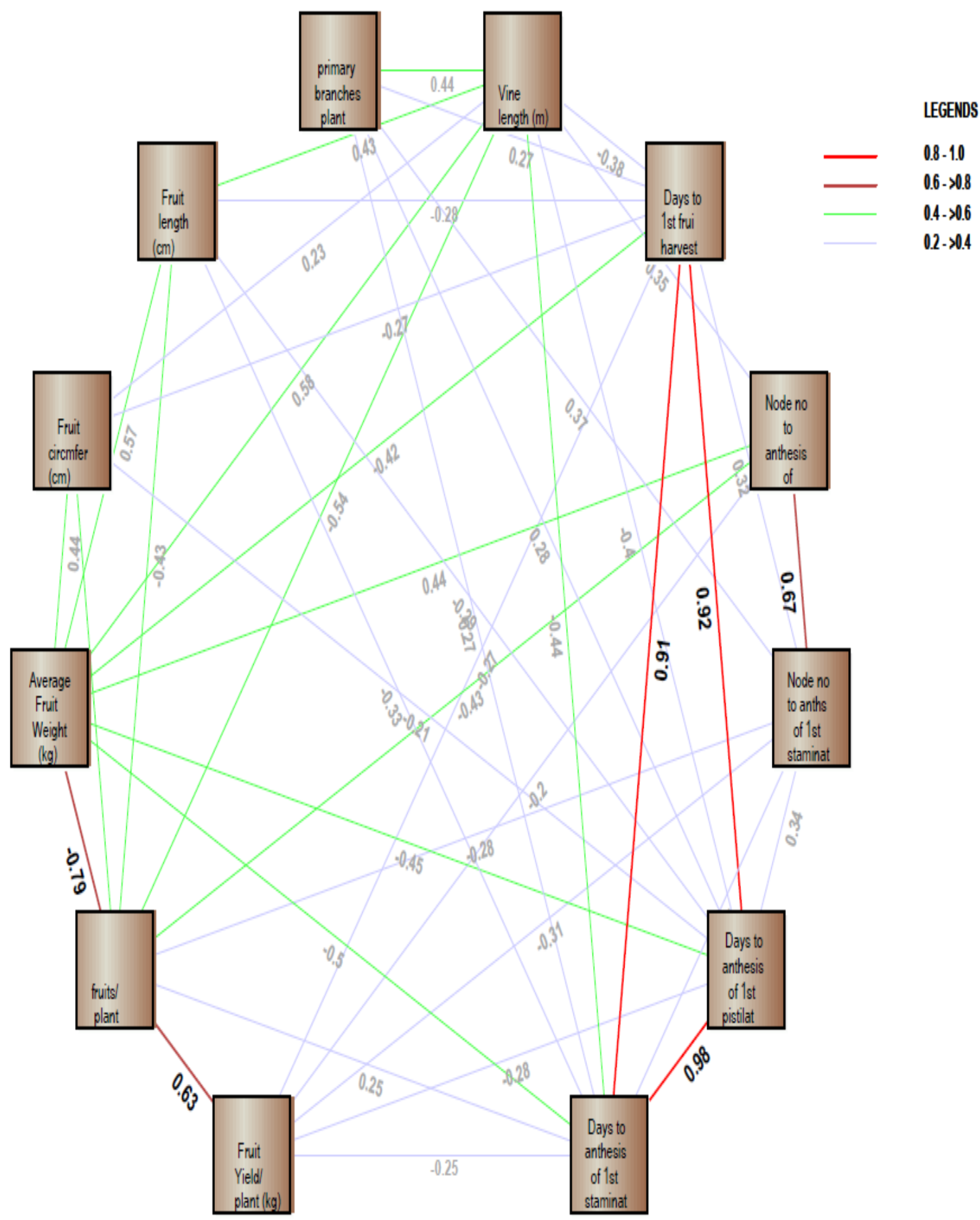




\section{Phenotypical Correlations}

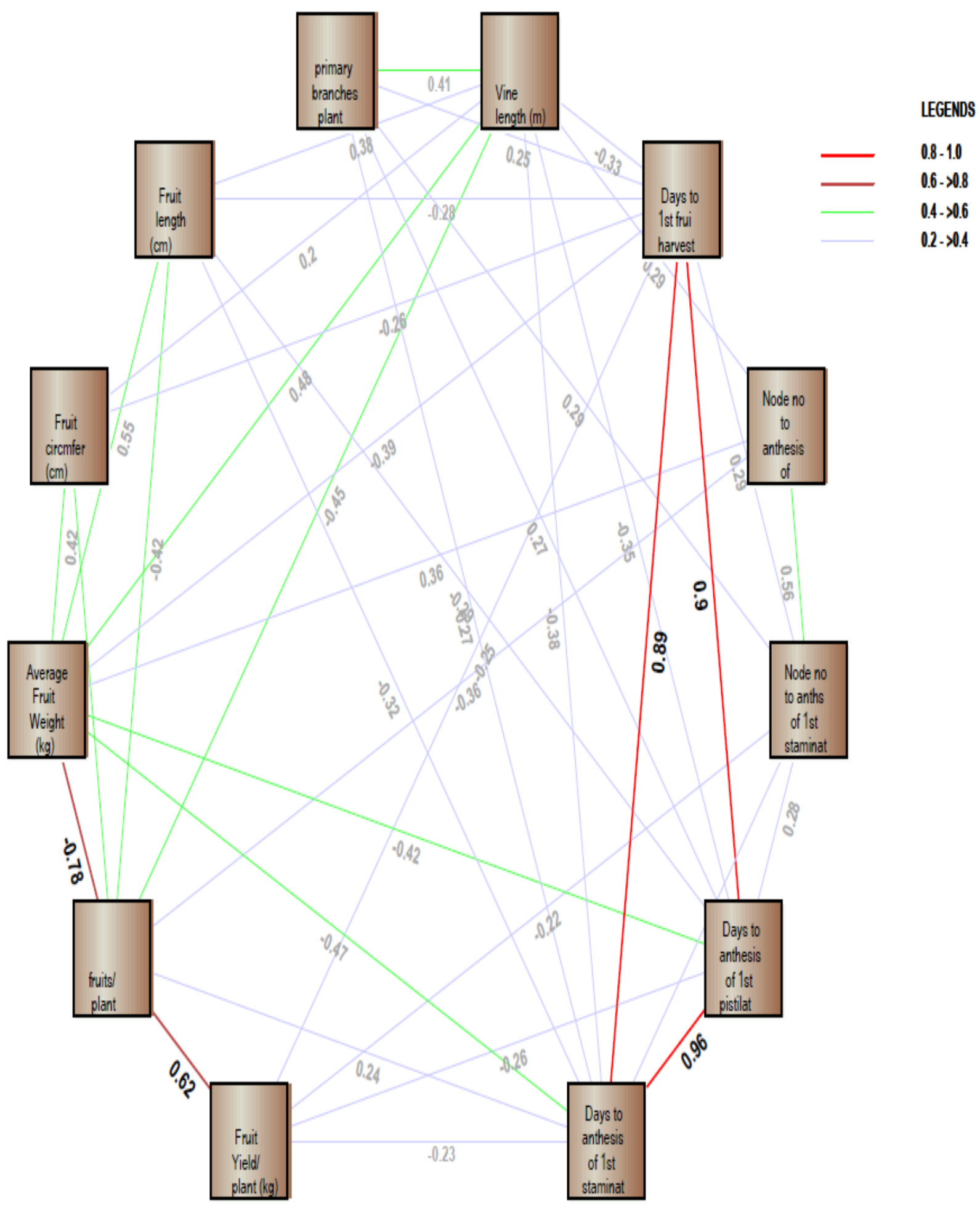




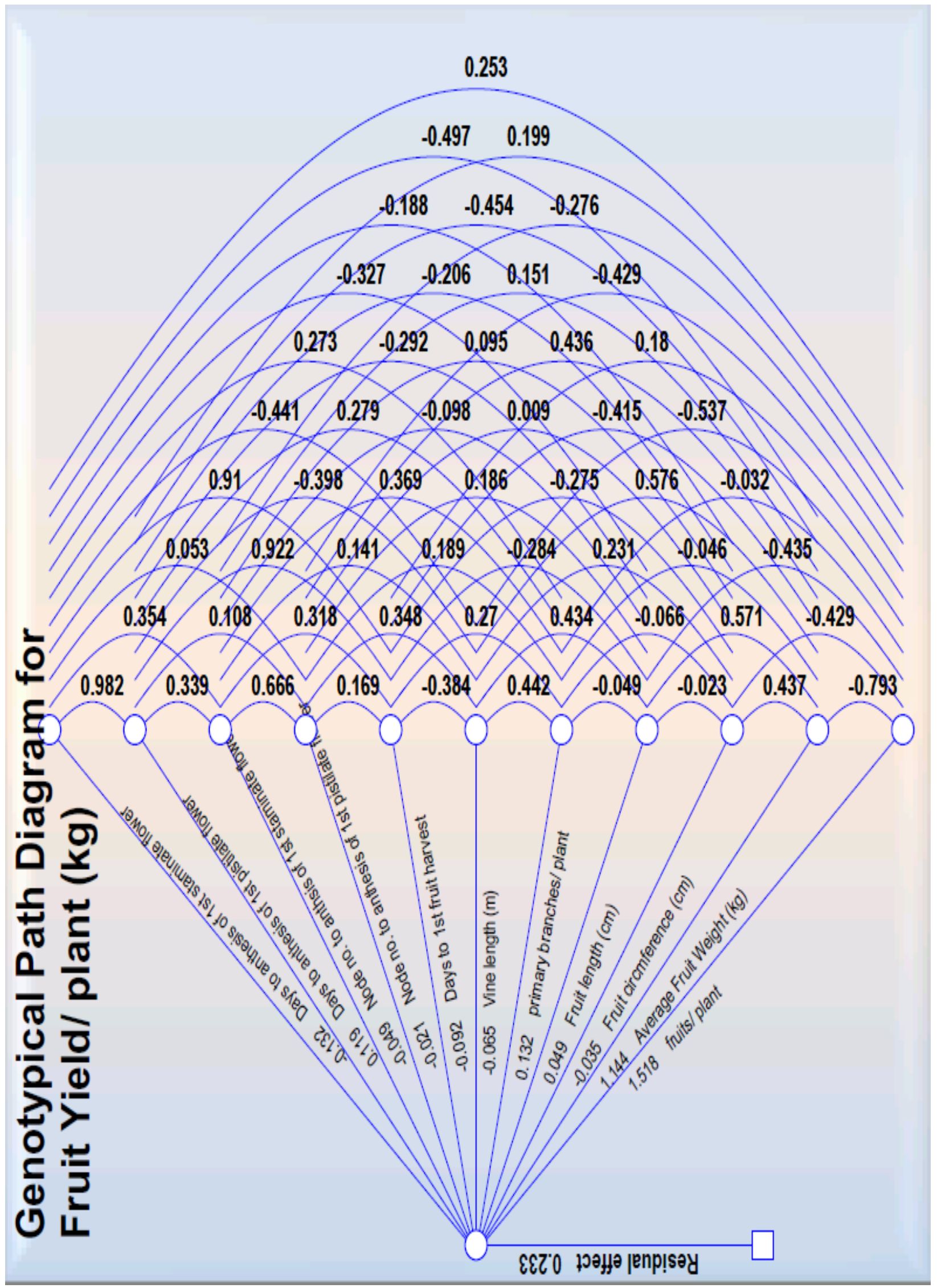




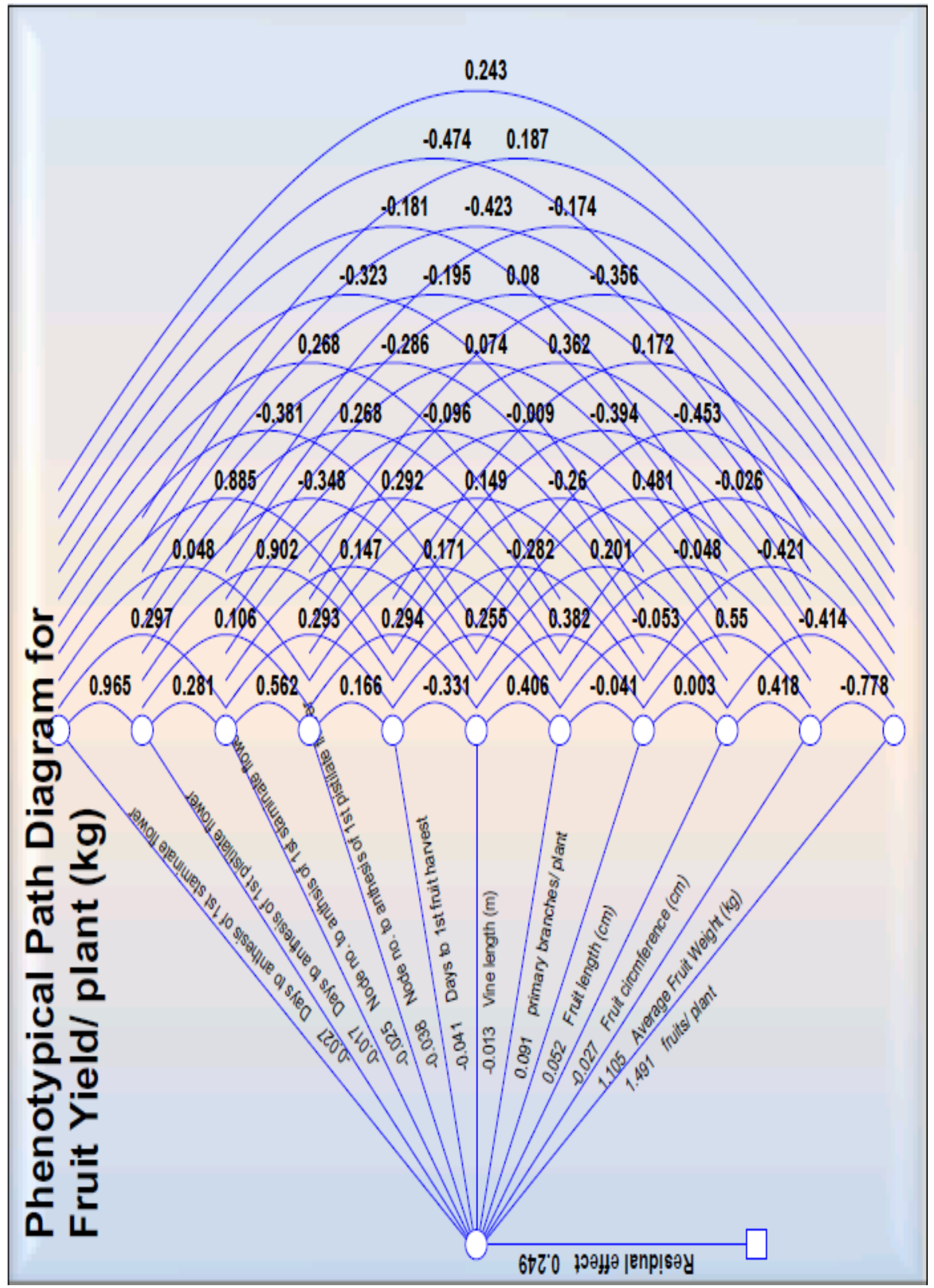


The indirect effects showed by most characters which influenced the yields are node number to staminate, pistillate flower anthesis, days to $1^{\text {st }}$ pistillate/staminate flower anthesis, vine length. This confers that more emphasis should be given to these traits that will be useful in bringing suitable line/genotype of higher yields in bottle gourd. The perusal overall results has positive impact on yield through simultaneous selection of the primary branches/plant, fruit length, average fruit weight and fruit/plant, are the principal component characters, which exhibited high positive direct effects. The indirect effects of most of the characters were for vine length, days to first staminate/pistillate flower anthesis, node number to $1^{\text {st }}$ staminate/pistillate flower anthesis; vine length and fruit circumference The final yield and yield attributing characters are basically governed by vegetative growth and its contributing traits like average fruit weight and number of fruits (Koppad et al., 2015). Correlation co-efficient matrix or path analysis for fruit yield in bottle gourd is the final character, which is contributed by a complex chain of interrelating characters. Association of this yield-contributing character with yield and among its components is important for making selection in the breeding program and facilitates the partitioning of correlation coefficients on the direct and indirect effects of component characters on yield and any other attributes.

\section{References}

Adarsh, A., Kumar, R., Kumar, A., Chaurasiya, J., Singh, H.K. and Roy, C.
2015. Combining ability analysis in bottle gourd [Lagenaria siceraria (Mol.) Standl.] for earliness and fruit yield. Green Farm., 6(5): 988-990.

Ara, Z.G., Zakaria, M., Uddin, M.Z., Rahman, M.M., Rasul, M.G. and Kabir, AFMR. 2014. Correlation matrix among different parameters of bottle gourd genotypes. Int. J. Natl. Social Sci., 1: 48-51.

Husna, A., Mahmud, F., Islam, M.R., Mahmud, M.A.A. and Ratna, M. 2011. Genetic Variability, Correlation and Path Co-Efficient Analysis in Bottle Gourd (Lagenaria siceraria L.). $A d v$. Biol. Res., 5(6): 323-327.

Janaranjani, K.G. and Kanthaswamy, V. 2015. Correlation Studies and Path Analysis in Bottle Gourd. J. Horticult., 2(1): 2-4.

Koppad, S.B., Chavan, M.L., Hallur, R.H., Rathod, V. and Shantappa, T. 2015. Variability and Character Association Studies in Ridge Gourd (Luffa acutangula Roxb.) With Reference To Yield Attributes. J. Global Biosci., 4(5): 2332-2342.

Parvathi, L., Nagabhushana, Reddy, E. 2006. Correlation studies in Bottle gourd (Lagenaria siceraria (Mol.) Standl.) J. Res. Angrau., 34: 98-100.

Seshadri, V.S. and Parthasarathy, V.A. 2002. Cucurbits. In: Vegetable Crops (Vol. I), Bose T. K. J. Kabir, T. K. Maity, V. A. Parthasarathy and M.G. Som (Eds) Naya prokash, Calcutta, India. pp. 493648.

\section{How to cite this article:}

Pankaj Kumar Ray, Anupam Adarsh, Sriom and Rajat Kumar Singh. 2017. Correlation Matrix on Bottle Gourd for Yield and its Attributing Traits. Int.J.Curr.Microbiol.App.Sci. 6(6): 12501259. doi: https://doi.org/10.20546/ijcmas.2017.606.146 